\title{
The Development of Borad game "The Adventure Of Algebra" in The Senior High School Mathematics Learning
}

\author{
Mei Andini' ${ }^{1}$, Tri Nova Hasti Yunianta ${ }^{2}$ \\ 1,2 Universitas Kristen Satya Wacana \\ Correspondence Address; 202015044@student.uksw.edu
}

\begin{abstract}
Abstrak
Algebra has an important meaning in Senior High School learning. It needs to be combined by the interesting practice questions, with that reason, this research will develop a board game learning media that can be used in Algebra learning. The research aims to develop a board game learning media that is valid, practical, and effective as a means of training questions in Algebraic material. The research uses the ADDIE development model which consists of steps Analyze, Design, Development, Implementation, and Evaluation. This media is a set of the modified game from monopoly games. This media is named The Adventure Of Algebra, and has been tested on 34 class VIII C students of SMP Negeri 1 Ambarawa. The instruments of data collection technique in the research consisted of instruments for validating material and media aspects, practicality assessment instruments, student opinion instruments, and posttest pretest instruments. The Media of board games have been declared valid from the aspect of material experts with a score of $95 \%$ and valid from media experts with a score of $96 \%$, both of which are very good categories. The results of practicality assessment get a score of $90 \%$ in the very good category. The results of the pair t-test data that show the sig value. (2-tailed) produced from the pretest and posttest data is written 0,000 which means that the significance value is close to zero which is less than 0.05 with the posttest average value (67) higher than the average pretest (50.5). So that the media is effective to be used as a means of training Algebra questions at the junior high school level.
\end{abstract}

Keyword:Algebra ; ADDIE; Board Game

\section{INTRODUCTION}

The Problem training in mathematics learning which is given in the classroom under the guidance of the teacher, the teacher's orders can largely weaken student initiative and creativity. Sometimes the exercises carried out repeatedly are monotonous and boring (Djamarah and Zain, 2010). Suwarnaning (2013) states that practice questions can also have a negative impact because students become bored in learning mathematics. Therefore, it is necessary for mathematics teachers to present practice questions more interestingly (Supriyono, 2012).

Sudjana and Rivai (1992) said that in order to realize the attractive learning process the attention of students, teachers can use learning media. One way to overcome students' boredom in the use of monotonous drill methods is using the drill method in the game method form. The use of games in the mathematics learning can help students increase motivation in learning (Murtadho and Tambunan, 1987).

The learning media is a tool that can convey or deliver learning messages (Arsyad, 2015). The use of interesting learning media will increase students' motivation and interest in the learning which will ultimately help students succeed in understanding the material (Setyadi and Qohar, 2017). 
The educational games are one of the offered solutions as innovative learning media (Pramuditya et al., 2018). The educational games can be a learning media that fun, has a series that is able to motivate The student. According to Nikensasi and Hakim (2012) the educational game is one of the game themes that seeks to provide educational value in a game so that games that initially only function as entertaining media, can also be used as media pembelajaran atau pelatihan. Therefore there is a need for teaching materials (other than textbooks) as the learning media that contains the educational games can help students get more leverage in the learning, because of the learning media will make students feel enjoy or not depressed in learning. The several forms of media games have been developed to be used in the mathematics learning, the example is game boarding.

According to Scorviano (Erlitasari and Dewi, 2016) in the History of the Board Game and Psychology. The board game games are where tools or parts of a game are placed, moved on a surface that has been marked or divided according to a set of rules. The media board game games need to be developed because there are currently many games that only contain cognitive aspects such as play stations and online games without regard to affective and psychomotor aspects which can cause students to have high individualism (Erlitasari and Dewi, 2016). In addition board games can be used as a channel for information and help in the learning process. That agreed with Gagne (Sadiman et al., 1990) states that the media are various types of components in the student environment that can stimulate learning. The use of shapes and colors that match with the characteristics of students and the challenges that exist in this board game, students will be more interested in understanding learning materials because they can learn while playing.

Several studies have proven the positive impact of using board game media on student learning outcomes. Some of studies include research Erlitasari and Dewi (2016) have developed integer line board media games in grade IV elementary school. Furthermore, the research Fathurrohman (2016) has developed a labyrinth game board for calculating operating material for elementary school. The research Ningrum and Mariono (2016) has developed board game visual media in the material of Junior high school Algebra form, as well as research Prasetyo (2018) which has developed the game of mathematical monopoly on the material of the straight line equations for class VIII junior high school. The results of the research concluded that the media created had a positive impact on students' interests and learning outcomes. The existence of the theory and results of the research, then as a form of follow-up efforts on existing problems, the researcher will develop media game board game learning.

Based on the results of previous research, an idea emerged to develop an media innovation in the form of an adventure board game, containing algebraic questions. The characteristics of algebraic material require real media as a medium for delivering interesting material. The use of board media game can make students interact directly with their friends so they can train communication between individuals and groups. The name of the board game that will be developed by the researcher is as"The Adventure of Algebra". Algebraic 
questions, in this game have been adjusted to the level of students' abilities so as to maximize results.

Therefore, the board game that will be developed is expected to improve the teacher's insight into the method of playing board games, overcome students' boredom in learning, and foster interest in learning. In addition, the board games can also be used as learning tools that are developed based on aspects of validity, practicality, and effectiveness especially for learning mathematics in Algebra material, as well as a means of training questions for the student and can be used by other teachers who can improve Learning Innovation (INOBEL).

\section{THE RESEARCH METHODS}

The research is Development Research or Research and Development ( $R$ \& D) (Sugiyono, 2009). Using the ADDIE model which consists of five stages, namely Analysis, Design, Development (Development), Implementation (Implementation), and Evaluation (Evaluation).The research uses data collection techniques in the form of validation questionnaires, material experts and media experts are used to measure the suitability of the material used and measure the feasibility of the media before being tested.

The media board game "The Adventure Of Algebra". The results of the material and media validation questionnaire assessment and practicality test results are qualitative and quantitative data. The assessment of practicality is done by the mathematics teacher in the class. Qualitative data in the form of input and criticism will be used as a reference to improve the board game learning media to be developed. Quantitative data in the form of results of assessment from material experts and media experts will be analyzed descriptively.

The criteria for expert assessment scores use the scale divided into 4 intervals, namely (1) strongly disagree, (2) disagree, (3) agree, (4) strongly agree which can be seen in Table 1. Formulas that can be used in calculating to obtain a percentage eligibility is formula (i). After the percentage of eligibility is obtained, categorization is carried out based on the provisions of Table 1.

$$
P(s)=\frac{s}{N} \times 100 \% \quad \ldots(i)
$$

\section{Description:}

$\mathrm{P}(\mathrm{s}) \quad=$ percentage of sub-variables

$\mathrm{S} \quad=$ number of scores for each sub variable

$\mathrm{N} \quad=$ maximum score

Tabel 1. The Categories Criteria of Learning media assessment result

\begin{tabular}{ccc}
\hline No & Interval & Criteria \\
\hline 1 & $83 \leq$ Score $100 \%$ & Strongly agree \\
2 & $62 \% \leq$ Score $<83 \%$ & Agree \\
3 & $41 \% \leq$ score $<62 \%$ & Disegree \\
4 & $20 \% \leq$ Score $<41 \%$ & Strongly Disagree \\
\hline
\end{tabular}


The results of the student opinion sheet in the form of qualitative data will be described to describe students' responses after using learning media. The results of the pretest and posttest were used as data to test the effectiveness of the media produced. The Processing data analysis using SPSS version 20 with a significant level of 5\%. In order to determine the mean difference test, a normality test with kolmogorov is carried out. If the normality test is not fulfilled, then a different mean test is carried out using the non parametric wiloxson test. If the normality test is fulfilled, then use the pair t-test.

The research hypothesis is the realization of board games that are valid, practical and effective. Board game are said to be valid if the results of material and media expert evaluations are at least $62 \%$. This media is practically used when the practicality assessment results are at least $62 \%$ and is said to be effective if there is a significant difference between the students' average pretest and posttest scores where the posttest value is higher.

\section{THE RESULTS OF THE RESEARCH AND THE DISCUSSION}

The $\mathrm{R} \& \mathrm{D}$ research aims to create learning media that are valid, practical and effective. The following steps of the research carried out based on the ADDIE model.

\section{Analyze}

The initial process carried out in this development is the analysis phase, that is curriculum analysis, the student characteristics analysis, and needs analysis. The curriculum applied at Junior High School 1 Ambarawa is Curriculum 2013 and KTSP. For class VII and VIII use the 2013 Curriculum. In the 2013 Curriculum there is a demand for learning that requires a learning process that can provide opportunities for students to develop all their potential. In addition, in the 2013 Curriculum students are required to find out rather than being told. Therefore the student must be required to be active in learning. The activating students can be carried out by giving a learning media that can attract students to learn information and knowledge given by the teacher. These activities can be carried out in groups, so as to make students active and the interaction between students.

At the age of 13-15 years old, the characteristics of students at that age still like to active. So from that the teacher must be able to provide a learning media in which have elements of the game. With the game students are expected to be active in the classroom and can interact well in their environment, he stage of needs analysis can be concluded that conventional problem training, namely exercises are likes students are given questions both from the LKS and questions sheet, can lead to student saturation in completing the questions training. There are many alternatives that can be used to stimulate students not to get bored in doing problem exercises, one of them is by packing the exercises into an interesting learning activity by playing the game. This challenge makes it necessary to modify board game so that it can be used in mathematics learning.

The game board that will be developed in the research is the board game that will be used as a means of training Algebra questions, so analysis of this material is needed. Algebraic material includes indicators namely (1) Identifying algebraic forms and their elements; (2) Complete the addition and reduction of algebraic forms; (3) Complete 
multiplication and algebraic division. Therefore, in developing this media it is necessary to pay attention to the scope of the material.

Design

The design phase is the most important stage in the development research process, where the media to be developed is done in this process. There are several things that must be discussed, namely the rules of the game, board games, reward cards, punishment cards, question cards, lendmark cards (property cards), coins, and pawns.

The first stage is to modify the rules of the game so that it can be used in the class as a group but still requires the existence of individual responsibility or the ability of individual students to work on the problem. This media is designed to be used in several groups according to the number of students in the class or outside the class. The design of the rules of the game can be seen in Figure 1. The purpose of board game games in general is to master all the plots above the board through the purchase, leasing, and exchange of property in a simplified economic system. But in this board game concept, there is a rule be given questions that must be answered by students who have the turn but the question must be done individually before the buying, renting and selling process. the purpose of the game for the students are be able to practice answering the questions.

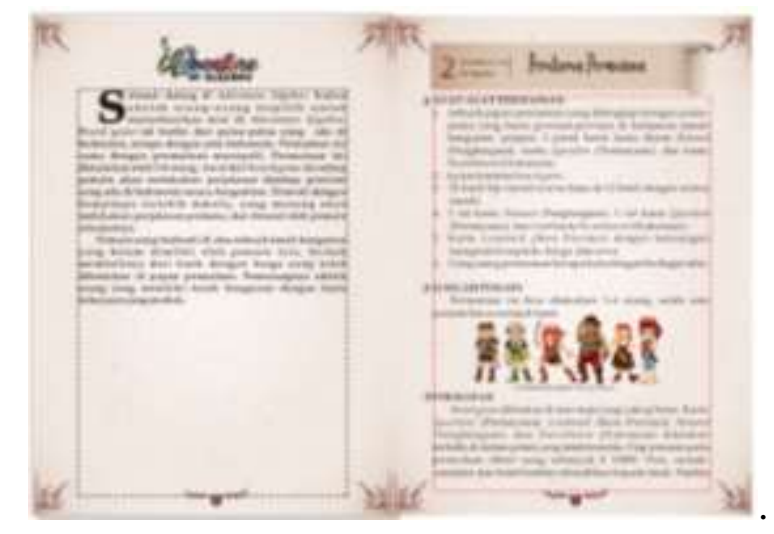

Figure 1. Games rules

After modifying the rules of the game, then designing the content (information / material and questions) in the form of algebra in accordance with the KD and indicators, determines the board game design to be developed according to the material, provides themes on the board game and arranges game support devices such as question cards, reward cards, punishment cards, lendmark cards (property cards), pawns and coins. After that, the concept was compiled and entered into the game board game media. The board games and cards are designed using CorelDRAW X7.4 software. The Board games and cards are designed with matching colors and images that match with the classic themes and The characteristicof students. Map board game design can be seen in Figure 2. 


\section{$\underset{\mathbf{a} \int}{\mathrm{a} \rho} \boldsymbol{\rho} \mu$}

Al-Jabar: Jurnal Pendidikan Matematika

Vol. 9, No. 2, 2018, Hal 95 - 109

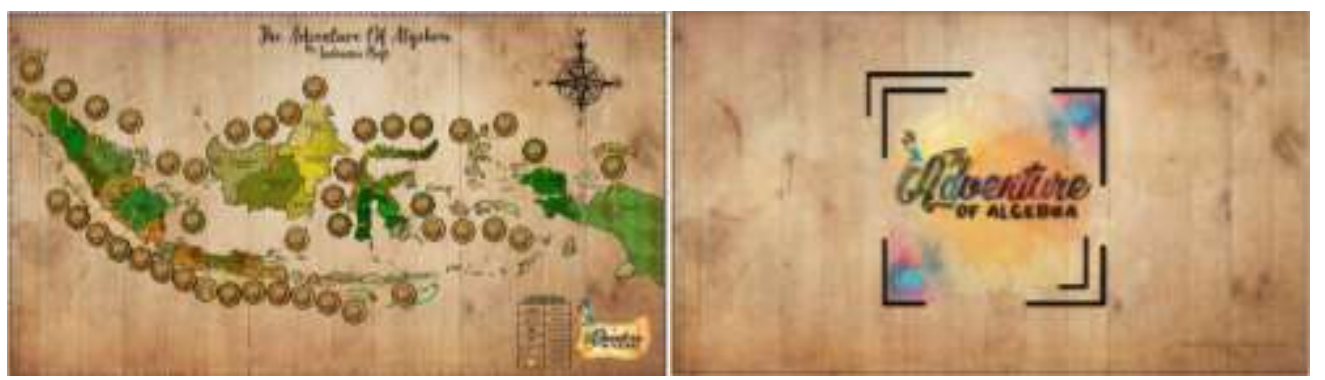

Figure 2. The Map of the Front Board Game, and The Map of the Rear Board Game

This map has a size of $42 \mathrm{~cm} \times 59.4 \mathrm{~cm}$, this size is equivalent to the size of A2 paper. The Maps are designed using CorelDRAW X7.4. The Maps are the most important component on the game board. The map function is as a container for the game. The map used is a map of Indonesia, with the aim that students better know the provinces in Indonesia. The Display of board game in the form of islands in Indonesia, each island consists of several provinces, with small islands in Indonesia used as Island rewards and Punishment Island, the island start and island prison. The use of Indonesian maps as a game board has been designed to make the board game more attractive as well as a means to foster a sense of nationalism in the souls of students. There are 34 provinces in Indonesia that are used on maps, all provinces are used to increase students' insight. It is likened students are simulated around Indonesia to enjoy every tourist attraction that becomes an icon in every province in Indonesia. In addition, they can learn about 34 provinces and their provincial capitals in Indonesia. The liaison between one province and the other provinces uses arrow lines and round and hexagonal blocks. The Attractive and colorful icons are characteristic of each province. For more attractive designs, each island is given a different color. Each province is given the name and price of building / provincial land. At the start of the match, the player's pawn is placed at the start, namely the Nanggro Aceh Darusalam Province, and so on. Each provincial plot is numbered so that it can simplify the pace of its journey. The Pion design can be seen in Figure 3

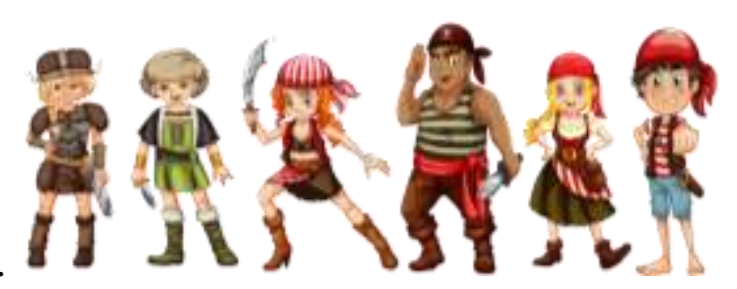

Figure 3. Pion Board Game

The Pion are designed using pirate characters, the goal is to increase students' interest in playing this board game, because most students are happy with unique and cool characters. In addition, this is also adjusted to the theme, namely the old times. 


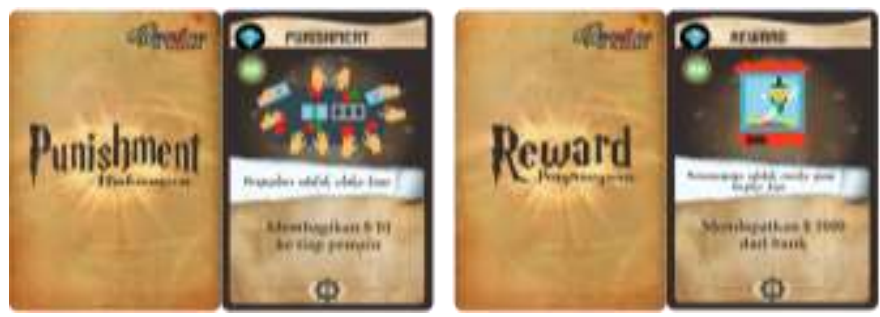

Figure 4. Reward Card and Punishment card

The question card or Reward Card has a size of $86 \mathrm{~mm} \times 59 \mathrm{~mm}$, the size of this card resembles The $\mathrm{Yu}$ gi $\mathrm{Oh}$ card . This card is designed using CorelDRAW X7.4. If the player stops at the reward, the player must take this card. This card contains gifts from the bank, gifts from other players, free of questions if the card owner cannot answer the question card, and is free from prison.

The Punishment Card has the size of $86 \mathrm{~mm} \times 59 \mathrm{~mm}$, the size of this card resembles a $\mathrm{Yu}$ gi oh Card. This card is designed using CorelDRAW X7.4. If the player stops at punishment, the player must take this card. This card contains punishments. The design of the reward card and punishment card can be seen in Figure 4.

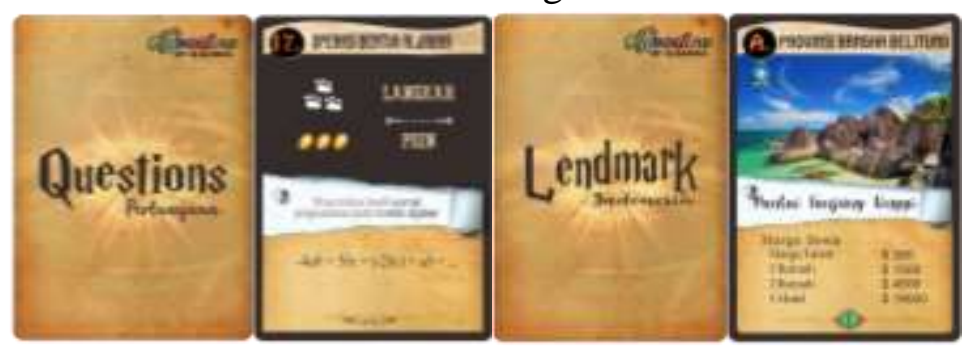

Figure 5. Question Card, and Lendmark Card (Icon)

The Question Cards have the size of $86 \mathrm{~mm} \times 59 \mathrm{~mm}$, the size of this card resembles a Yu gi oh card. the card is designed using CorelDRAW X7.4. The Question card designs can be seen in Figure 5. The design of the question card is adjusted to the color matching the trajectory that has been made. The function of this card is as the substitute for dice in a monopoly, in order to the player can walk. With the rule, if the player is able to work on the question and answer TRUE, the player advances according to the step number stated on the question. However, if the player's answer is FALSE, stop at the place. The number printed on the question card, serves as a step-by-step guide. The scarcity has also been adjusted to the level of difficulty question. If it's easy, the player can advance 1 to 2 steps. If the difficulty level is a moderate problem, then the player advances 3 to 4 steps, and if the level of the question is the difficult, target players step on 5 to 6 .

The Lendmark card or icon cards have a size of $86 \mathrm{~mm} \times 59 \mathrm{~mm}$, the size of this card resembles the Yu gi oh card. This card is designed using CorelDraw X7.4. The design can be seen in Figure 5. This card has tourist attractions in each of the Indonesian Provinces which become icons in each area. This is very good for giving insight to players who are played especially by junior high school students so that players know that in each province they have icons and tours that we need to know. The function of this card is as proof if the player has owned the building land / island of the province. the card contains the land rental price (when 
other players stop at the land, other players must pay the price of land rent to the owner), load the price of houses and hotels (price depends on the number of houses and hotels), purchase price of 1 house and 1 hotel (when the owner want to buy land for the building / province of the house or hotel).

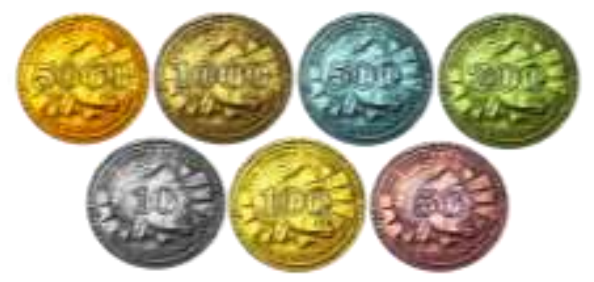

Figure 6. Board Game Coin

The coins on the game board have a size of $297 \mathrm{~mm} \times 420 \mathrm{~mm}$, for every 70 coins. This coin is designed using CorelDRAW X7.4. The Coin on the board game function as money to buy building / provincial land, pay fines, and deal with other players. There are 7 coins, namely $\$$ $5000, \$ 1000, \$ 500, \$ 200, \$ 100, \$ 50, \$ 10$. Before the game starts, the coins are shared with each player. Each player earns $\$ 15,000$, divided into various values of $\$ 5000$ for 1 coin, $\$ 1000$ for 7 coins, $\$ 500$ for 3 coins, $\$ 200$ for 4 coins, $\$ 100$ for 4 coins, and $\$ 50$ for 5 coins. The rest of the coins distributed to players are handed over to the bank.

Besides that there is also the board game book, the book is designed with a soft vintage theme. The book contains the rules of play and the introduction to what board games are, how to play, explained game tools in the board game, and answer keys on the game board. As well as the names of the provincial capitals of Indonesia. The book cover design can be seen in Figure 7. And the design of the book's contents can be seen in Figure 1.

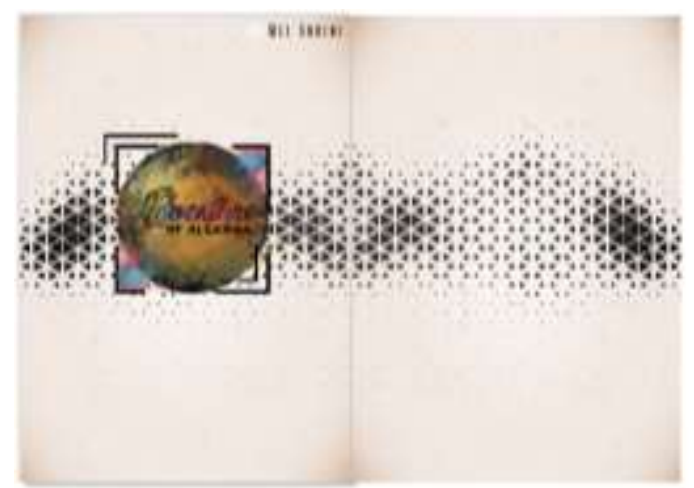

Figure 7. Board Game Book

This media design also pays attention to aspects of practicality in storage, so in this research the media was designed by packaging design in the form of a cardboard with several bulkheads . Cardboard is designed using CorelDRAW X7.4. The size of the cardboard is adjusted to the number of tools in the game, because it functions as a container on the game board. In the cardboard, the bulkheads are made whose function is to put coins, pion, houses or hotels and cards. This packaging uses a durable material that is thick and light yellowboard box. The selection of the yellow-board box is intended to be light when carried, and easy to maintain. The form of media packaging can be seen in Figure 8. 


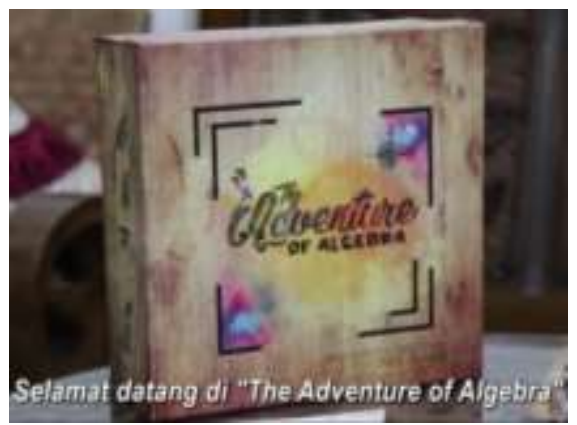

Figure 8. Board Game Packaging

In addition, the board games are equipped with equipment such as hotels and houses. Green houses and red hotels are used to mark the plots already owned by players. If the player wants to build the building. Home and hotel equipment can be seen in Figure 9.

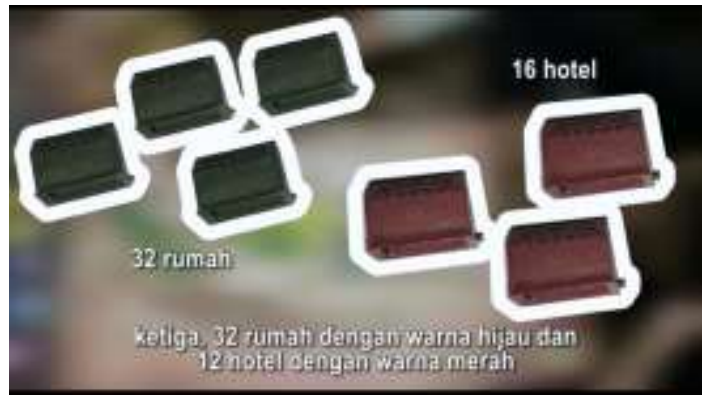

Figure 9. The houses and Hotels of Board Game

\section{Development}

Furthermore, after this research has produced products according to the design, do designed improvements, therefore at the stage of development the media is tested to the validator both in terms of material and media. The material validator consisted of junior high school 1 mathematics teacher, namely Ms. Eni Lestari, S. Pd in Junior High School 1 Ambarawa and an education mathematics lecturer of UKSW, Mrs. Erlina Prihatnani, S.Si, M.Pd. The results of this assessment can be seen in Table 2 .

Tabel 2. Material Validation Experts

\begin{tabular}{lcc}
\hline aspects of assessment & Percentage & Category \\
\hline Material aspects & $94 \%$ & Strongly agree \\
Contruction aspects & $96 \%$ & Strongly agree \\
Avarage & $95 \%$ & Strongly agree \\
\hline
\end{tabular}

Based on the recap in Table 2. It appears that the material aspects and construction aspects, both of them are in the strongly agree category. The two material validators considered that the questions on the board game had varied and included indicators in Algebraic material. In addition, the level of difficulty in the question is also in accordance with the ability of students so that the media is declared valid from the aspects of mathematical material.The media validator consisted of The mathematics teacher of Junior High School 1 Ambarawa namely Mrs. Eni Lestari S.Pd and mathematics education lecturer of UKSW Mrs. Erlina Prihatnani, S.Si, M.Pd. The results of this assessment can be seen in Table 3. 
Tabel 3. Media Validation Experts

\begin{tabular}{lcc}
\hline Aspects of assessment & Percentage & Category \\
\hline Media Display & $92 \%$ & Strongly Agree \\
Game Rule & $88 \%$ & Strongly Agree \\
Creating & $100 \%$ & Strongly Agree \\
Using and treatment & $96 \%$ & Strongly Agree \\
Package & $100 \%$ & Strongly Agree \\
Advantage & $100 \%$ & Strongly Agree \\
\hline Avarge & $96 \%$ & Strongly Agree \\
\hline
\end{tabular}

Based on the recap in Table 3. It appears that the six aspects of the media assessment are categorized as strongly agree. The two media validators considered that on the display aspect of the media in the form of media names, game board design, card design, card size and game boards and equipment were appropriate. On the rules aspect of the simple game is the validator judges accordingly. On the aspect of making media is easily available, affordable judgments and validators are appropriate. In the aspect of use and maintenance in the form of durable media, the validator is used accordingly. In the packaging aspect in the form of media storage and easy to carry media, the validator assesses accordingly. While the aspects of the usefulness of the media have the principle of learning and playing, the media fosters an element of fun, and the media makes the active student validator assess that aspect is appropriate. So it can be concluded that the media is declared valid from the aspect of mathematical media.

Based on Table 2. and Table 3. it can be concluded that board game media is valid to be used as the means of training questions in Algebraic material.The validator of material experts considered that the media has a theme withThe unique design. In addition, the combination of colors with the size of the product and the type of font that match, and this media has a complete component. The results are similar to the results of the research conducted by (Wulandari and Budiharti, 2016), (Musfiqi and Jailani, 2014), (Latief, 2017), (Widianingtyas and Budiharti, 2017), (Setyaningsih and Dewi, 2015), (Nurwani et al., 2017), (Winarso and Yuliyanti, 2017), (Harsono and Prihatnani, 2018), dan (Setyadi, 2017) the researcher who shows that media games are valid and suitable for learning.

\section{Implementation}

After the media was declared valid to be used, the next step of this media was tried out to 34 class VIII C students of Junior High School 1 Ambarawa. The activity was held for 3 meetings. The first meeting was to do The pretest to find out the students' initial abilities. The second meeting was for media use and the third meeting was to do The posttest to determine the ability of students after being given a game board game.

The obstacle when using media is the arrangement of media usage preparation. During the board game process there is one group that reaches the finish and performs board game rounds in less than 60 minutes with each student working on 4-8 questions. But there were also The number of groups who completed the game and questions with a considerable amount of time from the specified duration, even there were groups that could not finish until the finish of the game until the appointed time was up. As for the time needed to complete the game with quite a long time. 
The recapitulation of the results of practicality sheets, this practicality test was carried out by one teacher, Mrs. Eni Lestari S.Pd. The validator gives advice and input the results of the Practicability Test recapitulation can be seen in Table 4.

Tabel 4. Validation Practical Tests

\begin{tabular}{lcc}
\hline Aspects of assessment & Percentage & Catogory \\
\hline Manufacture aspects & $92 \%$ & Strongly Agree \\
Preparation for Use & $82 \%$ & Strongly Agree \\
Aspects of use & $96 \%$ & Strongly Agree \\
Avarage & $90 \%$ & Strongly Agree \\
\hline
\end{tabular}

Can be seen as a whole the practicality test results from the aspect of manufacture including the category strongly agree because the teacher assesses that the game board is durable to be used, and the media is easy to maintain. From the aspect of preparation for use, it also falls into the very good category because the teacher considers that board games are easy to carry, and that to play board games no other tools or materials are needed. Nevertheless the percentage is lower than the other aspects, this is due to the lack of time management before starting the application of board game media because before the game process the researcher must go around each group to share media and explain verbally to help each group to prepare the board game so much students who often ask when the game process has begun. As for the aspect of usage, it falls into a very good category because the teacher considers board games to be easy to play.

The practical test results in Table 4. show that practical game board media to be used as a means of training questions in Algebraic material. This is similar to research (Indrawati et al., 2013) That was said that the resulting media are practically used. The teacher as who was given the assessment of the practicality test argues that this media can be used repeatedly and through this media makes students more active. However, this media has the disadvantage things, which requires the long time to prepare, but in fact this is due to the arrangement of the media and classrooms which take up waste time.

\section{Evaluation}

This media was tested on the student who had received Algebra material. In this study, the effectiveness of media use is measured by the achievement of learning outcomes, so that before this media is given, the students are first given the test. This test aims to obtain pretest data before being given treatment. Then The students are given the opportunity to use the media. Whereas after being treated the students were again given a test which aimed to get the posttest. The test provided consists of 15 multiple choice questions covering all three sub-material of Algebra. The pretest and posttest questions have similarities in the level of diversity and difficulty of the questions. The recapitulation of the results can be seen in Table 5 .

Tabel 5. The Result of Pretest and Posttest

\begin{tabular}{cccccc}
\hline & \multicolumn{2}{c}{ Grade } & Avarage & $\begin{array}{c}\text { Std. } \\
\text { Deviation }\end{array}$ & N \\
\cline { 2 - 4 } & Max & Min & & 11.9 & 34 \\
\hline Pretest & 73 & 33 & 50.5 & 13.4 & 34 \\
\hline Posttest & 87 & 40 & 67.0 &
\end{tabular}

The posttest average (67) was better than the average pretest (50.5), the meaning of the increase in the average pretest that had not yet reached the minimum completeness the increased criteria at the 
posttest which approached the completion of minimal scores. In order to see whether the media is effective or not, the difference average test is conducted between the pretest and posttest. To find the type of test, the normality test is carried out. The normality Test Results can be seen in Table 6.Tabel 6.

The result of Normality test

\begin{tabular}{lcccccc}
\hline & \multicolumn{3}{c}{ Kolmogorov-Smirnov } & \multicolumn{3}{c}{ Shapiro-Wilk } \\
& Statistic & df & Sig. & Statistic & Df & Sig. \\
\hline Pretest & .135 & 34 & .123 & .926 & 34 & .023 \\
Posttest & .141 & 34 & .083 & .932 & 34 & .035 \\
\hline
\end{tabular}

The results of the Kolmogorov-Smirnov normality test showed that the significance value of pretest 0.123 and posttest 0.083 where the results were more than 0.05 , so that it can be concluded that the pretest and posttest samples were each in a normally distributed population so that the difference avarege test was used with the parametric test pair t-test. The results of the T-Test Pair Test can be seen in Table 7.

Table 7. The result test of Paired Sample T-test

\begin{tabular}{lccccccccc}
\hline & \multicolumn{9}{c}{ Paired Differences } \\
& Mean & $\begin{array}{c}\text { Std. } \\
\text { Deviation }\end{array}$ & $\begin{array}{c}\text { Std. } \\
\text { Error } \\
\text { Mean }\end{array}$ & \multicolumn{2}{c}{$\begin{array}{c}\text { 95\% Confidence } \\
\text { Interval of the } \\
\text { Difference } \\
\text { Lower }\end{array}$} & Tper & df & $\begin{array}{c}\text { Sig. (2- } \\
\text { tailed) }\end{array}$ \\
\hline Pair 1 & Pretest-posttest & -16.5 & 16.8 & 2.9 & -22.4 & -10.7 & 5.8 & 33 & .000 \\
\hline
\end{tabular}

The results test of the pair t-test data show that the sig value. (2-tailed) produced from the pretest and posttest data is written 0,000 which means that the significance value is close to zero which is less than 0.05 with the posttest average value (67) better than the average pretest (50.5). So that this media is effective to be used as a means of training Algebra questions at the junior high school level. These results support (Dara et al., 2016), (Farida and Suryadinata, 2016), (Kharisma and Sugiman, 2017) which showed that Algebra learning media able to improve mathematics learning outcomes effectively. Therefore, it can be concluded that effective board game media is used as a means of training questions in Algebraic material. The difference is also seen with the increasing of students in the medium category who increased to students in the very high category. In addition, there is also a recapitulation of student opinions. The results of the Student Opinion Recapitulation can be seen in Table 8 .

Table 8. The Recapitulation of Student Opinions toward the media

\begin{tabular}{lccl}
\hline \multirow{2}{*}{ Indicators } & \multicolumn{2}{c}{ Description (\%) } & \multirow{2}{*}{ Conclusion } \\
\cline { 2 - 3 } & Agree & Disagree & \\
\hline The Rule of Game & $71 \%$ & $29 \%$ & Agree \\
The media is easy to use & $71 \%$ & $29 \%$ & Agree \\
The Opportunities of success & $53 \%$ & $47 \%$ & Agree \\
The Preparing of game & $74 \%$ & $26 \%$ & Agree \\
Improve the student's Interest & $62 \%$ & $38 \%$ & Agree \\
The Interesting Packaging & $91 \%$ & $9 \%$ & Agree \\
addicted to play again & $62 \%$ & $38 \%$ & Agree \\
Playing and learning & $100 \%$ & - & Agree \\
The useful Media & $97 \%$ & $3 \%$ & Agree \\
\hline
\end{tabular}

Based on the recap of Table 8. It appears that the game rules and media indicators are easy to use, both of them are in the agreed category. In addition, The student thinks that this 
media is easy and fun to play. The student also assumes that by using this media The students can be playing and learning and through this media students also become more active. The capitulation of student opinions towards the media is concluded to agree. The results of this study are similar to the results of research conducted by the research (Prasetyo, 2018). (Sidarta and Yunianta, 2017), (Salafudin et al., 2018), (Pangesti and Retnowati, 2017), (Rizal and Hernawati, 2017), (Ningrum and Mariono, 2016), (Listiani and Prihatnani, 2018). The results of the study concluded that the media created had the positive impact on students' interests and learning outcomes. As well as learning media that are developed valid, practical, and effective as learning media.

\section{CONCLUSIONS AND SUGGESTIONS}

The research results stated that the board game media "The Adventure of Algebra" was valid from the material aspect and the learning media with a percentage of $95 \%$ and $96 \%$ both included in the category strongly agree. The value of practicality in the media is $90 \%$ including the very practical category. The results of the pair t-test data test show that the sig value. (2-tailed) produced from the pretest and posttest data is written 0,000 which means that the significance value is close to zero which is less than 0.05 with the posttest average value (67) higher than the average pretest (50.5). So that this media is effective to be used as a means of training Algebra questions at the junior high school level. Based on the results of the overall test, it can be concluded that the board game media "The Adventure of Algebra" is valid, practical, and effective for use as a learning media for Algebra material at junior high school level.

Suggestions in this study, for teachers to be able to use this media well. $\mathrm{n}$ addition, for other researchers to develop media board games on other material, by having the same material characteristics, and use the map of your province as The media board game to be developed, in order to introduce culture in each province. This media can inspire the teacher or other researcher to innovate in developing board game learning media that can be used as a means to practice questions.

\section{REFERENCES}

Arsyad, A. (2015). Media Pembelajaran (Edisi Revisi). Rajawali Pers, Jakarta.

Dara, H.R., Fadli, Yanto, Y., (2016). Pengembangan Media Permainan Ular Tangga Matematika Materi Operasi Aljabar Pada Kelas VIII SMP Negeri 7 Lubuklinggau Tahun Pelajaran 2016/2017. Alumni STKIP-PGRI Lubuklinggau 1-14.

Djamarah, Z. (2010). Strategi Belajar Mengajar. Reneka Cipta, Jakarta.

Erlitasari, N.D., Dewi, U., (2016). Pengembangan Media Board Game Garis Bilangan Materi Bilangan Bulat Mata Pembelajaran Matematika Kelas IV SDN Ngampelsari Candi Sidoarjo. J. Mhs. UNESA 1-12.

Farida, N., Suryadinata, N., (2016). Pengembangan Bahan Ajar Mata Kualiah Aljabar Linear Berbasis Open Ended. Aksioma, 5, 145-151. 
Fathurrohman, M., Nindiasari, H., Rahayu, I., (2016). Pengembangan Board Game Matematika Di SD Negeri Wadasari Kabupaten Serang. Eprints UNY 465-472.

Harsono, D.N., Prihatnani, E., (2018). Pengembangan Permainan Domat Card Pada Materi Sistem Persamaan Linier Satu Variabel. MAJU 5, 1-13.

Indrawati, D., Suardiman, S.P., Uny, Pp., (2013). Pengembangan Media Travel Game untuk Pembelajaran Perkalian dan Pembagian Bilangan Pecahan Matematika SD Kelas V. $J$. Prima Edukasia 1, 12.

Kharisma, J.Y., Sugiman, (2017). Pengembangan Bahan Ajar Matematika Berbasis Masalah Berorientasi Kemampuan Pemecahan Masalah dan Prestasi Belajar Matematika. JPMS IV, 142-151.

Latief, M., (2017). Pengembangan Permainan Ular Jarpa Sebagai Media Pembelajaran Pada Materi Pokok Asam-Basa. Jurna Penelit. Pendidik. Insani 20, 101-107.

Listiani, D., Prihatnani, E., (2018). Pengembangan Media Pembelajaran Dart Board Math Bagi Siswa Kelas VII SMP. Math Didact. 4, 21-33.

Murtadho, S., Tambunan, (1987). Pengajaran Matematika. Karunika Universitas Terbuka, Jakarta.

Musfiqi, S., Jailani, (2014). Pengembangan Bahan Ajar Matematika yang Berorientasi pada Karakter dan Higher Order Thinking Skill (HOTS). Pythagoras 9, 45-59.

Nikensasi, P., Hakim, J.A.R., (2012). Rancang Bangun Permainan Edukasi Matematika dan Fisika dengan Memanfaatkan Accelerometer dan Physics Engine Box2d pada Android 1,6 .

Ningrum, S.S., Mariono, A., (2016). Pengembang Media Visual Papan Permainan Pada Materi Bentuk Aljabar Mata Pelajaran Matematika Kelas VII SMP Siti Aminah Surabaya. J. Mhs. UNESA 7.

Nurwani, Putra, R.W.Y., Putra, F.G., Putra, N.W., (2017). Pengembangan Desain Didaktis Bahan Ajar Materi Pemfaktoran Bentuk Aljabar pada Pembelajaran Matematika SMP. Numerical 1, 193-206.

Pangesti, F.T.P., Retnowati, E., (2017). Pengembangan Bahan Ajar Geometri SMP Berbasis Cognitive Load Theory Berorientasi pada Prestasi Belajar Siswa. Pythagoras 12, 33 46.

Pramuditya, S.A., Noto, M.S., Purwono, H., (2018). Desain Game Edukasi Berbasis Android pada Materi Logika Matematika. 2, 165-179.

Prasetyo, M.F., (2018). Persamaan Garis Lurus bagi Siswa Kelas VIII SMP Negeri. 5, 14-26. 
Rizal, A., Hernawati, K., (2017). Pengembangan Game Edukasi Matematika Dengan Pendekatan Guided Discovery Untuk Siswa SMP Kelas VII. Jurnal Pendidik. Mat. 6, $1-8$.

Sadiman, A.S., Raharjo, R., A. Haryono, (1990). Media Pendidikan: pengertian, pengembangan, dan pemanfaatannya, 1st ed. CV. Rajawali, Jakarta.

Salafudin, Pramesti, S.L.D., Juwita Rini, (2018). Pengembangan Bahan Ajar Matematika SMP Berwawasan Nasionalisme Dan Kemandirian. MaPan 6, 20-30.

Setyadi, D., (2017). Pengembangan Mobile Learning berbasis Android sebagai Sarana Berlatih Mengerjakan Soal Matematika. Satya Widya 33, 87-92.

Setyadi, D., Qohar, A., (2017). Pengembangan Media Pembelajaran Matematika Berbasis Web Pada Materi Barisan Dan Deret. Kreano J. Mat. Kreat.-Inov. 8, 1-7.

Setyaningsih, M.D., Dewi, N.R., (2015). Pengembangan Media Papan Permainan Berbasis Scince Edutainment Tema Makanan Untuk Siswa Kelas VIII. USEJ 4, 965-972.

Sidarta, K.T., Yunianta, T.N.H., (2017). Pengembangan Kartu Domano (Domino Matematika Trigono) sebagai Media Pembelajaran pada Mata Kuliah Trigonometri. Program Studi Pendidik. Mat. FKIP-UKSW.

Sudjana, N., Rivai, A., (1992). Media Pengajaran: Penggunaan dan Pembuatannya. Sinar Baru, Bandung.

Sugiyono, (2009). Metode Penelitian Pendidikan. Alfabeta, Bandung.

Supriyono, (2012). Mengenal Tugass Akhir Program. Widya Sari Press, Salatiga.

Suwarnaning, D., (2013). PTK Rumah Perkalian Isi. CV. Sinar, Jakarta.

Widianingtyas, F.I., Budiharti, (2017). Pengembangan Media Pembelajaran Papan Bajahitam (Bahasa Jawa dan Hitung Matematika) Ditinjau Dari Prestasi Belajar Siswa Kelas IV Di SDN Suryodiningrat 3 Yogyakarta. J. PGSD Indonesia. 3, 1-16.

Winarso, W., Yuliyanti, D.D., (2017). Pengembangan Bahan Ajar Matematika Berbentuk Leaflet Berbasis Kemampuan Kognitif Siswa Berdasarkan Teori Bruner. JIPM 6, 1124.

Wulandari, D.G.R., Budiharti, (2016). Pengembangan Media Pembelajaran Kantong Nilai Plastik Transparan Untuk Menanamkan Konsep Operasi Hitung Bilangan Disekolah Dasar. Respository UPY. 